О.М. Литвяк ${ }^{1}$, С.В. Комар ${ }^{2}$

${ }^{1}$ Національний університет ичивільного захисту Украӥни, Харків

${ }^{2}$ Харківський національний університет Повітряних Сил ім. I. Кожедуба, Харків

\title{
ОБҐРУНТУВАННЯ ЗАКОНІВ РЕГУЛЮВАННЯ ГІДРОГАЛЬМІВНОЇ УСТАНОВКИ ДЛЯ НАЗЕМНИХ ВИПРОБУВАНЬ ТУРБОВАЛЬНИХ ГТД
}

У статті розглядаються проблеми, щэо виникають при наземних випробуваннях авіаційних турбовальних газотурбінних двигунів на гідрогальмівних установках. Представлені експериментальні завантажувальні характеристики гідрогальма $i$ несучого гвинта вертольота. Показано, шьо невідповідність завантажувальних характеристик гідрогальма відповідним характеристикам несучого гвинта може призвести до незадовільної роботи регулятора частоти обертання ротора вільної турбіни двигуна. Дано обтрунтування закону регулювання завантаженням гідрогальма, щзо забезпечує завантажувальні характеристики близькі до завантажувальних характеристик несучого гвинта вертольота. Показано, щз гідрогальмівна установка з системою автоматичного керування завантаженням дозволяє наблизити динамічні характеристики гідрогальма до динамічних характеристик несучого гвинта вертольота і забезпечити коректні наземні випробування турбовальних ГТД.

Ключові слова: наземні випробування турбовальних ГТД, гідрогальмо, завантажувальна характеристика, динамічні параметри, закон регулювання, перехідні характеристики, регулятор частоти обертання вільної турбіни.

\section{Вступ}

Постановка проблеми. При наземних випробуваннях турбовальних ГТД (ТВаД) часто відзначається незадовільна робота системи автоматичного регулювання частоти обертання вільної турбіни, яка проявляється як сталі коливання параметрів двигуна. У окремих випадках має місце безперервне зростання амплітуди коливань аж до спрацьовування автоматичних систем захисту вільної турбіни від небезпечного розкручування.

При роботі ТВАД в складі силової установки вертольота вільна турбіна здійснює обертання несучого гвинта вертольота (НГ). При автоматичному регулюванні частоти обертання НГ об'єктом регулювання є вільна турбіна (ВТ) 3 підключеним гвинтом (ВТ+НГ).

При наземних випробуваннях ТВаД на гідрогальмівній установці (ГГУ), об'єктом регулювання є вільна турбіна 3 підключеним гідрогальмом $(\mathrm{BT}+\Gamma \Gamma)$.

ГГУ розраховується на певну споживану потужність, а завантажувальні характеристики і інерційні властивості гідрогальма визначаються його конструктивними особливостями.

Слід зазначити, що завантажувальні характеристики і інерційні властивості ГГУ істотно відрізняються від завантажувальних характеристик і інерційних властивостей НГ вертольота. Ця відмінність може призводити до незадовільної роботи регулято- ра частоти обертання вільної турбіни (РЧОВТ) при наземних випробуваннях двигуна спільно з ГГУ.

Зміна конструкції ГГ з метою зміни його характеристик дуже трудомістке і дороге завдання. Тому актуальним є пошук рішень, що забезпечують емуляцію заданих характеристик простими засобами автоматики.

Аналіз останніх досліджень і публікацій. Безперервне вдосконалення авіаційних ТВаД вимагає такого ж безперервного вдосконалення ГГУ для проведення наземних випробувань, яке здійснюється як шляхом розробки і впровадження нових, так i модернізацією вже існуючих установок.

У роботі [1] розглядається питання розробки $\mathrm{i}$ застосування пневмогальма для наземних випробувань ГТД. Проте повітряне гальмо розглядається не як спосіб зміни динамічних параметрів гальмівної установки, а як засіб здешевлення розробки гальмівної установки шляхом застосування компресорів низького тиску існуючих ГТД.

Одним з нових напрямів удосконалення випробувальних стендів є застосування автоматизованих систем керування при проведенні наземних випробувань авіаційних ГТД. При розробці автоматизованих систем керування наземними випробуваннями авіаційних ГТД основна увага приділяється автоматизованим системам збору і обробки даних [2-3]. Проте в цих роботах розглядаються можливості автоматизації випробувань авіаційних ГТД, як засіб виміру параметрів на усталених режимах роботи 
двигуна. Можливості засобів автоматизації для керування гальмівним моментом не розглядалися.

Питанням автоматизації випробувальних стендів з урахуванням динаміки процесів при випробуваннях двигунів на гідрогальмівних установках присвячені роботи [4-6]. У цих роботах розглядається динаміка валу ГГ (власні і вимушені коливання). Засоби автоматизації тут застосовуються 3 метою забезпечення стійкості системи вимірювань в умовах динамічних навантажень. Динаміка систем автоматичного регулювання частоти обертання ротора ВТ поблизу точки рівноваги не розглядалась.

У роботах [7-8] розглядаються причини виникнення низькочастотних коливань при випробуваннях двигунів на гідрогальмівних установках. У [7] представлена модель розрахунку збудження низькочастотних коливань в системі вимірів реактивного моменту високочастотними коливаннями тиску потоку рідини. Проте ця модель не дозволяе пояснити виникнення автоколивань параметрів двигуна або його нестійку роботу в області роботи РЧОВТ. У [8] відзначається, що можливими причинами виникнення низькочастотних коливань частоти обертання ВТ є взаємодія двигуна і ГГ, але до кінця ці причини авторам виявити не вдалося.

У [9-10] розглянуті питання проектування і виготовлення гідрогальмівних стендів для випробувань різних типів двигунів. У роботі [9] даються рекомендації щодо вибору параметрів заново проектованих гідрогальмівних пристроїв. Проте способи зміни завантажувальних характеристик і їх адаптація до характеристик реальних об'єктів не розглядаються. У статті [10] піднімаються проблеми створення новітніх гідрогальмівних установок 3 можливістю емуляції характеристик гребних і повітряних гвинтів. Проте конкретних даних про способи керування гідрогальмом, результатів розрахунку або експериментальних даних не наводиться.

Як показав аналіз літературних даних, питанням моделювання динамічних характеристик реальних об'єктів на гідрогальмівних установках засобами автоматизації не приділено достатньо уваги. Об'єктивно це пов'язано з тим, що на гідрогальмівних установках випробовуються різні об'єкти, у тому числі і не схильні до розвитку коливань. Для таких складних об'єктів, якими є ТВаД, питання взаємодії системи автоматичного керування двигуном з гідрогальмівною установкою $є$ надзвичайно важливим. Проблема полягає в тому, що параметри регулятора частоти обертання вільної турбіни (РЧОВТ) вибираються відповідно до параметрів НГ і не відповідають параметрам ГГУ при наземних випробуваннях. Вирішенням проблеми може стати система автоматичного керування крутним моментом ротора ГГУ, що забезпечує повну емуляцію динамічних параметрів НГ.
Це дозволяє зробити висновок про доцільність проведення досліджень 3 розробки і створення автоматизованих систем керування завантаженням ГГУ.

Мета статті Метою даної роботи є обгрунтування структури і законів регулювання системи автоматичного регулювання (САР) гідрогальмівною установкою, призначеною для наземних випробувань ТВаД. Автоматизація гідрогальмівних установок дозволить усунути невідповідність динамічних параметрів ГГУ динамічним параметрам несучих i гребних гвинтів і забезпечить коректну роботу САР частоти обертання вільної турбіни при наземних випробуваннях ТВаД.

Для досягнення поставленої мети необхідно вирішити ряд завдань:

- виконати математичний опис об'єкту дослідження;

- обгрунтувати закон регулювання завантаженням ГГУ;

- виконати дослідження динаміки САР ГГУ.

\section{Виклад основного матеріалу}

Об'єктом дослідження є система автоматичного регулювання частотою обертання вільної турбіни $\left(\mathrm{CAP}\left(n_{\text {вт }}\right)\right)$ ТВаД, яка включає:

- динамічну модель (ВТ+ГГ);

- динамічну модель (ВТ+НГ);

- динамічну модель регулятора ГГ.

Розглянемо рівняння динаміки ротора [11] вільної турбіни, що обертається, з ГГ:

$$
\frac{\pi I_{(B T+\Gamma \Gamma)}}{30} \frac{d n_{B T}}{d t}=M_{B T}-M_{\Gamma \Gamma} ;
$$

де $I_{(B T+\Gamma Г)}$ - приведений момент інерції ротора вільної турбіни і ротора гідрогальма;

$n_{B T}$ - частота обертання ротора ВТ;

$M_{B T}-$ крутний момент ВТ;

$M_{Г \Gamma}-$ момент опору ГГ.

Рівняння динаміки ротора вільної турбіни, що обертається, з НГ

$$
\frac{\pi I_{(B T+H \Gamma)}}{30} \frac{d n_{B T}}{d t}=M_{B T}-M_{H \Gamma},
$$

де $I_{(B T+H \Gamma)}$ - приведений момент інерції ротора вільної турбіни і ротора НГ;

$M_{H \Gamma}$ - момент опору НГ.

У загальному виді крутний момент вільної турбіни та моменти опору ГГ і НГ є складними функціями:

$$
\begin{gathered}
M_{B T}=M_{B T}\left(n_{B T} ; n_{T K} ; P_{B}^{*} ; T_{B}^{*}\right), \\
M_{\Gamma \Gamma}=M_{\Gamma \Gamma}\left(n_{B T} ; \alpha_{\Gamma \Gamma} ; t_{B}\right), \\
M_{H \Gamma}=M_{H \Gamma}\left(n_{B T} ; \varphi_{H \Gamma} ; P_{B}^{*} ; T_{B}^{*}\right),
\end{gathered}
$$


де $n_{T K}$ - частота обертання ротора турбокомпресора (ТК) двигуна;

$P_{B}^{*}-$ повний тиск повітря на вході в двигун;

$T_{B}^{*}$ - повна температура повітря на вході в двигун;

$t_{B}$ - температура води на вході в ГГ;

$\alpha_{\Gamma \Gamma}-$ положення крана, що регулює витрату води через ГГ;

$\varphi_{H \Gamma}-$ кут установки лопатей НГ.

Для спрощення будемо вважати, що випробування двигуна проходять на землі в умовах стандартної атмосфери. Це дозволить на початковому етапі нехтувати впливом зміни зовнішніх умов $P_{B}^{*} ; T_{B}^{*} ; t_{B}$.

3 урахуванням прийнятих допущень рівняння ротора ВТ, що обертається, в лінійній постановці і у відносних змінних для (ВТ+ГГ) матиме вид [4]:

$$
T_{\Gamma \Gamma} \stackrel{\bullet}{n}_{B T}+\bar{n}_{B T}=K_{\Gamma \Gamma / n_{T K}} \bar{n}_{T K}+K_{\Gamma \Gamma / \alpha_{\Gamma \Gamma}} \bar{\alpha}_{\Gamma \Gamma},(6)
$$

де $T_{\Gamma Г}$ - стала часу ротора (BТ $\left.+\Gamma Г\right), \mathrm{c}$;

$\bar{n}_{B T}$ - відносна частота обертання ротора ВТ;
$\stackrel{\bullet}{n}_{B T}=\frac{d \bar{n}_{B T}}{d t}-$ відносна швидкість змінення частоти обертання ротора ВТ;

$K_{\Gamma \Gamma / n_{T K}}=\frac{\Delta \bar{n}_{B T}}{\Delta \bar{n}_{T K}}-$ коефіцієнт впливу (підсилення) частоти обертання ротора турбокомпресора на частоту обертання ВТ;

$$
K_{\Gamma \Gamma / \alpha_{\Gamma \Gamma}}=\frac{\Delta \bar{n}_{B T}}{\Delta \bar{\alpha}}-\text { коефіцієнт впливу (підси- }
$$

лення) положення регулюючого крану ГГ на частоту обертання ВТ.

Рівняння динаміки в лінійній постановці об'єкту $(\mathrm{BT}+\mathrm{H \Gamma})$ :

$$
T_{H \Gamma} \stackrel{\bullet}{n}_{B T}+\bar{n}_{B T}=K_{H \Gamma}{ }_{n_{T K}} \bar{n}_{T K}+K_{H \Gamma / \varphi_{H \Gamma}} \bar{\varphi}_{H \Gamma}
$$

Значення коефіцієнтів підсилення $K_{H \Gamma} / n_{T K}$ i $K_{\Gamma \Gamma / n_{T K}}$ можна визначити із завантажувальних характеристик НГ і ГГ (рис. 1):

$$
K_{H \Gamma / n_{T K}}=\frac{\Delta \bar{n}_{B T}}{\Delta \bar{n}_{T K}} ; \quad K_{\Gamma \Gamma / n_{T K}}=\frac{\Delta \bar{n}_{B T}}{\Delta \bar{n}_{T K}} .
$$

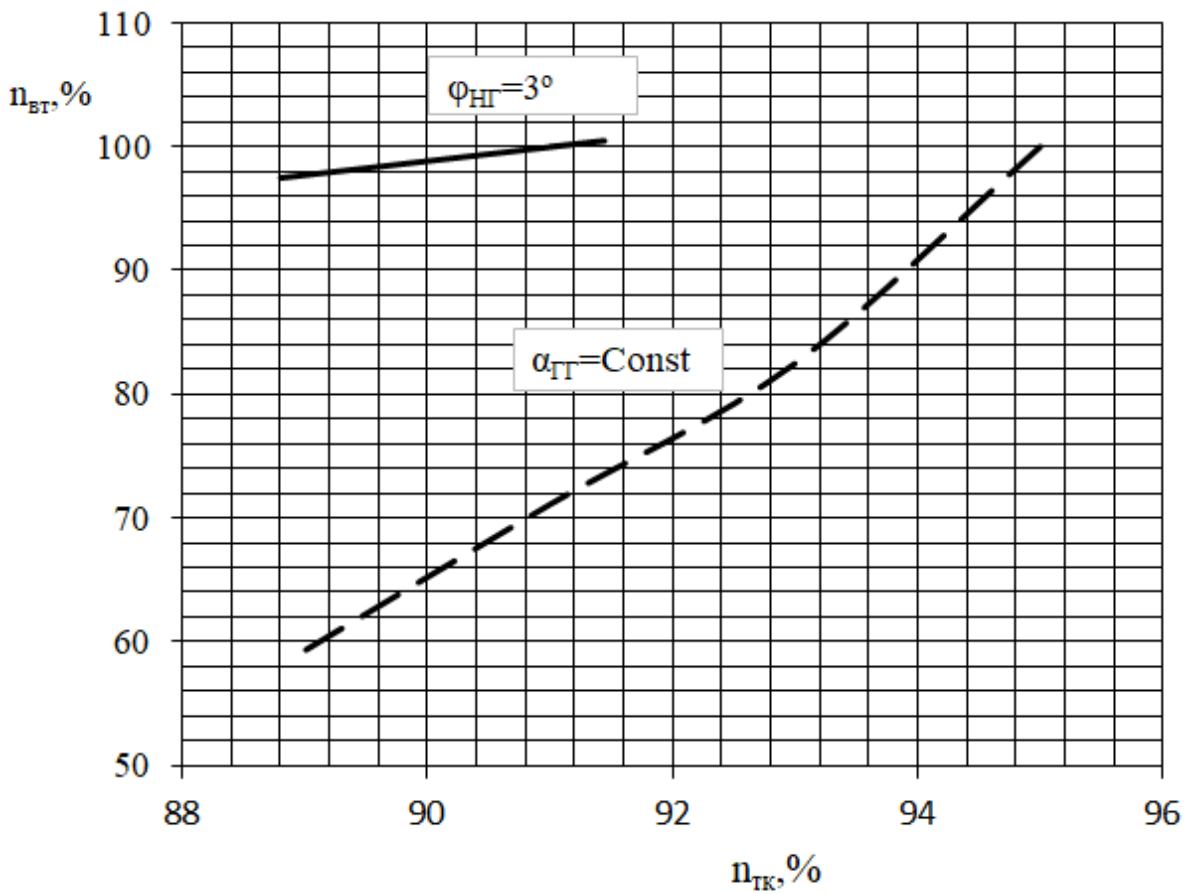

Рис. 1. Завантажувальна характеристика НГ і ГГУ

3 рис. 1 видно, що об'єкт (ВТ+ГГ) набагато “гостріше” реагує на зміну частоти обертання ТК (потужності) двигуна, ніж об'єкт (ВТ+НГ). Тобто приріст частоти обертання ВТ при однаковій зміні частоти обертання ТК у гідрогальма більше, ніж у НГ:

$$
K_{\Gamma \Gamma / n_{T K}}>K_{H \Gamma / n_{T K}} .
$$

Рівняння динаміки (ВТ+ГГ) і (ВТ+НГ) за структурою однакові, але динамічні параметри різні. Тому для збереження подібності динамічних процесів досить дотримання рівності:

$$
\begin{aligned}
T_{\Gamma \Gamma} & =T_{H \Gamma}, \\
K_{\Gamma \Gamma / n_{T K}} & =K_{H \Gamma} / n_{T K} .
\end{aligned}
$$


За відомими рівняннями динаміки об'єкту ресхему САР ( $\left.n_{\text {гг }}\right)$ (рис. 2). гулювання можна скласти структурно-динамічну

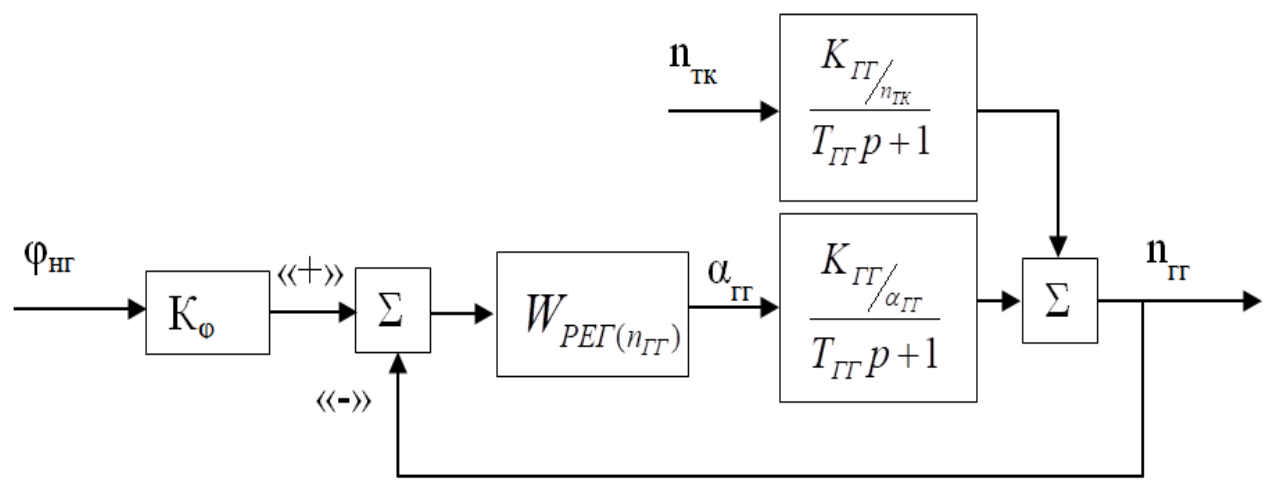

Рис. 2. Структурно-динамічна схема САР $\left(n_{\text {гг }}\right)$

Передатна функція САР $\left(n_{\text {гг }}\right)$ при зміні частоти обертання ТК має вид:

$$
\begin{aligned}
& W_{C A P\left(n_{\Gamma \Gamma}\right)}= \\
& =\frac{K_{\Gamma \Gamma} / n_{T K}}{\left(T_{\Gamma \Gamma} p+1\right)+W_{p e r}\left(n_{\Gamma \Gamma}\right)} \cdot K_{\Gamma \Gamma / \alpha_{\Gamma \Gamma}} .
\end{aligned}
$$

Передатна функція регулятора в загальному випадку має вид:

$$
W_{p e z\left(n_{\Gamma \Gamma}\right)}=\frac{A_{\text {pez }}(p)}{L_{p e \tau}(p)},
$$

де $A_{\text {рег }}(p)$ - поліном чисельника передатної функції регулятора;

$$
L_{\text {рег }}(p) \text { - поліном знаменника передатної фу- }
$$
нкції регулятора;

$$
p \text { - оператор Лапласа. }
$$

3 аналізу передатних функцій $W_{p e г\left(n_{\Gamma \Gamma}\right)}$ i $W_{C A P\left(n_{\Gamma Г}\right)}$ виходить:

А) щоб зберегти вид і порядок рівняння динаміки $\mathrm{CAP}\left(n_{\text {гг }}\right)$, що відповідає рівнянню НГ характеристичний поліном знаменника передатної функції регулятора повинен прагнути до одиниці, а поліном чисельника не повинен перевищувати перший порядок;

Б) щоб забезпечити незалежний вплив на коефіцієнт підсилення і сталу часу САР $\left(n_{\text {гг }}\right)$ чисельник передатної функції регулятора повинен містити два незалежних коефіцієнта.

Таким чином, передатна функція регулятора в стандартному виді повинна відповідати реальному форсуючому коректорові:

$$
W_{p e г\left(n_{\Gamma \Gamma}\right)}=\frac{K_{\Phi}\left(T_{\Phi} p+1\right)}{T_{p e z} p+1} .
$$

де $K_{\Phi}-$ коефіцієнт підсилення регулятора;

$T_{\Phi}$ - стала часу форсуючого коректора;

$T_{\text {peг }}$ - стала часу регулятора.
Як було відмічено вище, стала часу регулятора має бути малою величиною $T_{p e z} \approx 0$. В цьому випадку інерційністю самого регулятора можна нехтувати. 3 урахуванням цього визначимо передатну функцію САР $\left(n_{\text {гг }}\right)$ з форсуючим коректором при зміні частоти обертання ТК:

$$
W_{C A P\left(n_{\Gamma \Gamma}\right)}=\frac{\frac{K_{\Gamma \Gamma} / n_{T K}}{1+K_{\Phi} K_{\Gamma \Gamma} / \alpha_{\Gamma \Gamma}}}{\left(\frac{T_{\Gamma \Gamma}+K_{\Phi} K_{\Gamma \Gamma} T_{\Phi}}{1+K_{\Phi} K_{\Gamma \Gamma} / \alpha_{\Gamma \Gamma}}\right) p+1} .
$$

Позначимо:

$$
\begin{gathered}
K_{C A P_{\Gamma \Gamma}}=\frac{K_{\Gamma \Gamma} / n_{T K}}{1+K_{\Phi} K_{\Gamma \Gamma} / \alpha_{\Gamma \Gamma}}, \\
T_{C A P_{\Gamma \Gamma}}=\frac{\left(T_{\Gamma \Gamma}+K_{\Phi} K_{\Gamma \Gamma / \alpha_{\Gamma \Gamma}} T_{\Phi}\right)}{1+K_{\Phi} K_{\Gamma \Gamma / \alpha_{\Gamma \Gamma}}} .
\end{gathered}
$$

Отримаємо передатну функцію в стандартному виді:

$$
W_{C A P\left(n_{\Gamma \Gamma}\right)}=\frac{K_{C A P_{\Gamma \Gamma}}}{T_{C A P_{\Gamma \Gamma}} p+1} .
$$

Звідси можна визначити параметри регулятора, що забезпечують такі ж динамічні параметра стабілізованого ГГ, як і у НГ:

$$
\begin{gathered}
\frac{K_{\Gamma \Gamma} / n_{T K}}{1+K_{\Phi} K_{\Gamma \Gamma} / \alpha_{\Gamma \Gamma}}=K_{H \Gamma}, \\
\frac{\left(T_{\Gamma U}+K_{\Phi} K_{\Gamma \Gamma} \alpha_{\Gamma \Gamma} T_{\Phi}\right.}{1+K_{\Phi} K_{\Gamma \Gamma / \alpha_{\Gamma \Gamma}}}=T_{H \Gamma} .
\end{gathered}
$$


Вирішивши отриману систему рівнянь (19), (20), отримаємо значення параметрів регулятора для конкретного НГ:

$$
\begin{gathered}
K_{\Phi}=\left(\frac{\frac{K_{\Gamma \Gamma} / n_{T K}}{K_{H \Gamma} / n_{T K}}-1}{K_{\Gamma \Gamma} / \alpha_{\Gamma \Gamma}}\right), \\
T_{\Phi}=\frac{T_{H \Gamma}\left(1+K_{\Phi} K_{\Gamma \Gamma / \alpha_{\Gamma \Gamma}}\right)-T_{\Gamma \Gamma}}{K_{\Phi} K_{\Gamma \Gamma / \alpha_{\Gamma \Gamma}}} .
\end{gathered}
$$

Дослідження динаміки $\mathrm{CAP}\left(n_{\text {гг }}\right)$ завантаженням гідрогальмівної установки були виконані для динамічних параметрів НГ і ГГ, близьких до реальних значень. На рис. 3 показана зміна частоти обертання ВТ при роботі з НГ і нестабілізованим ГГ з наступними параметрами:

$$
\begin{gathered}
K_{H \Gamma / n_{T K}}=1,5, \quad T_{H \Gamma}=2, c, \quad K_{\Gamma \Gamma}=5,9, \\
T_{\Gamma \Gamma}=0,8, c, \quad K_{\Gamma T} /_{\alpha_{\Gamma \Gamma}}=3 .
\end{gathered}
$$

3 рис. 3 видно, що динаміка ВТ з нестабілізованим ГГ не відповідає динаміці (ВТ+НГ). Відмінність частоти обертання ротора ГГ від частоти обертання НГ в перехідному процесі може досягати до 4 разів.

На рис. 4 показана зміна частоти обертання ВТ при роботі ТВаД з НГ і стабілізованим ГГ для різних значень сталої часу регулятора $T_{\text {рег }}$. Параметри форсуючого коректора регулятора, розраховані за формулами (21), (22), взяті наступними:

$$
K_{\Phi}=0,978, T_{\Phi}=2,41, c .
$$

Як видно з рис. 4, перехідні процеси $\operatorname{CAP}\left(n_{\text {гг }}\right)$ залежать від сталої часу (швидкодії виконавчого механізму) регулятора.

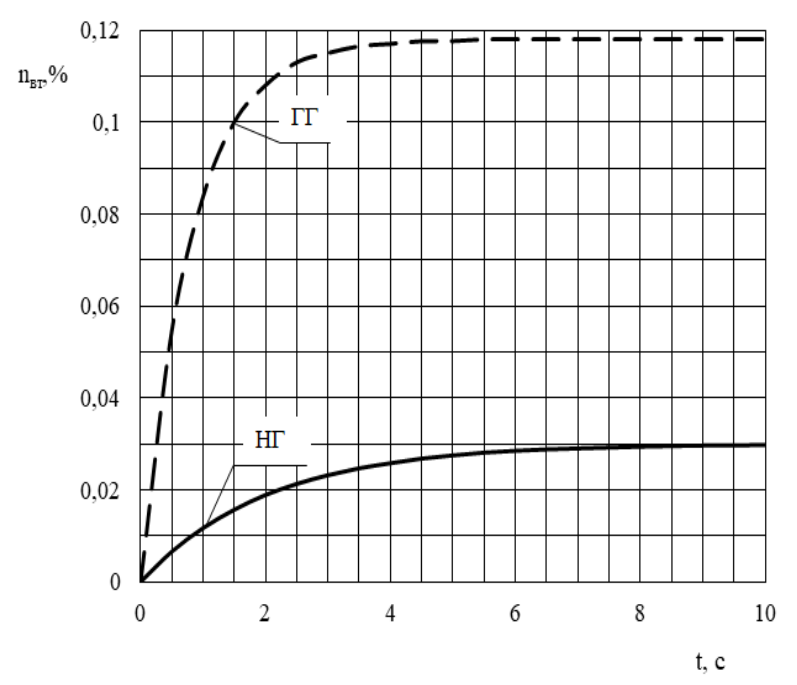

Рис. 3. Перехідний процес ВТ при роботі ТВаД з НГ і нестабілізованою ГГУ

Видно, що якщо стала часу регулятора на порядок вище сталої часу ГГУ:

$$
T_{p e z}=0,1 \cdot T_{\Gamma \Gamma},
$$

то в перехідному процесі відмінність частоти обертання ротора стабілізованого ГГ від частоти обертання НГ не перевищує 1,5\%. Змінюючи динамічні параметри регулятора, можна забезпечити подібність динамічних випробувань НГ різних вертольотів.

\section{Висновки}

1. Запропонований простий спосіб зміни динамічних параметрів ГГУ для моделювання характеристик НГ різних вертольотів.

2. Дано теоретичне обгрунтування застосування пропорційно-диференціювального закону регулювання завантаженням ГГУ.

Показано, що для забезпечення подібності динамічних параметрів $(\mathrm{BT}+\Gamma \Gamma)$ i $(\mathrm{BT}+\mathrm{H} \Gamma)$ стала часу регулятора має бути малою величиною, тобто виконавчий механізм регулятора має бути швидкодіючим.

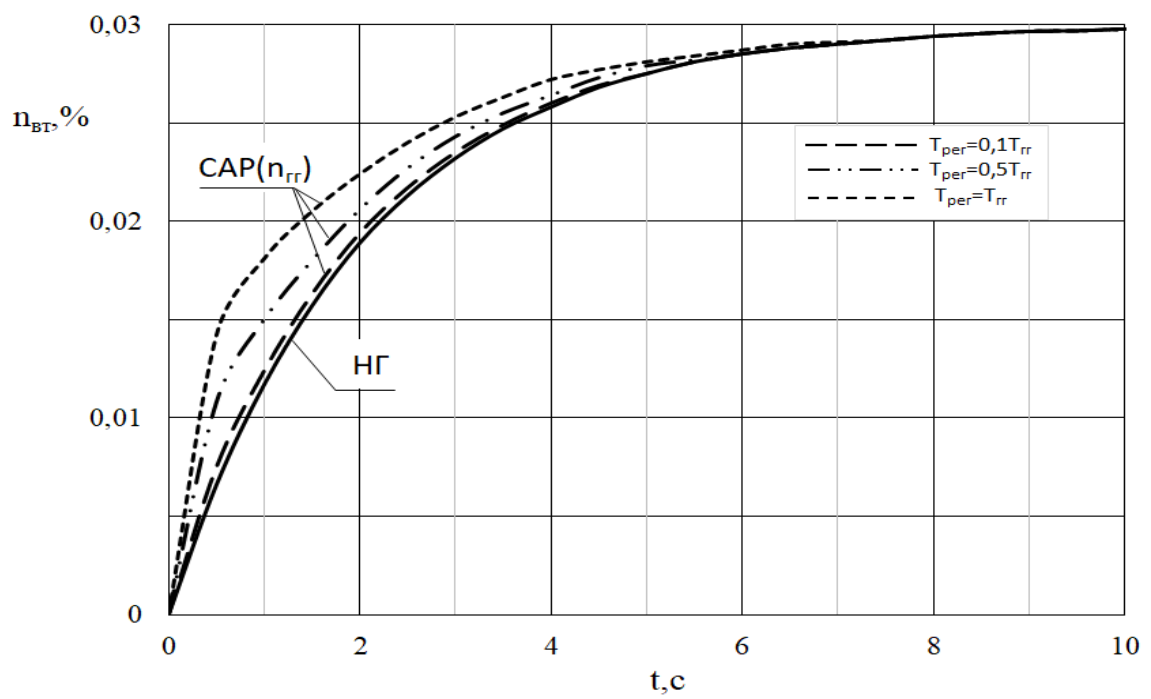

Рис. 4. Перехідний процес ВТ при роботі ТВаД з НГ і стабізованою ГГУ 
3. Розроблена лінійна динамічна модель системи автоматичного регулювання завантаженням гідрогальма. Отримана еквівалентна передатна функція $\mathrm{CAP}\left(n_{\text {вт }}\right)$ гідрогальмівної установки, що дозволяе розрахувати параметри регулятора $\left(K_{\phi}, T_{\phi}\right)$ під задані динамічні параметри реального об'єкту (НГ).

4. Виконані розрахункові дослідження перехідних процесів несучого гвинта і гідрогальма без стабілізації із системою автоматичного керування завантаженням.

Показано, що при визначені параметрів регулятора за запропонованими формулами i при достатній швидкодії виконавчих механізмів, можна забезпечити перехідні процеси $\mathrm{CAP}\left(n_{\text {гг }}\right)$ близькими до перехідних процесів НГ.

Відмінність частоти обертання ротора стабілізованої ГГУ від частоти обертання НГ в перехідному процесі не перевищує 1,5\% (рис. 4).

\section{Список літератури}

1. Попов Г.М. Использование компрессора низкого давления для создания гидротормозной системы испытательного стенда газотурбинных двигателей / Г.М. Попов, Ю.Д. Новикова, Е.С. Горячкин // Материалы международной научнотехнической конференции. - Самара, СНИУ. - 2016. - Ч. 2. - С. 132-133.

2. Система автоматизации серийных стендовых испытаний авиационных двигателей / Л. Хаит, Р. Хусаинов, В. Солдатов, М. Головин // Современные технологии автоматизации. - 2018. - № 4. - С. 76-81.

3. Опыт разработки и применения интеллектуальных испытательных стендов авиационных газотурбинных двигателей при доводке цифровых САУ / В.А. Седристый, С.В. Лозня, С.А. Пустовой, И.И. Степаненко // Вестник инженерной академии Украины. - 2009. - № 1. - С. 158-164.

4. Sykes C.L., Sagehorn K.H. Systems and Methods for Controlling the Stability of a Water Brake Dynamometer. United States Patent US7.942.249 B2.

5. Adaptive control of engine torque with input delays / E. Gruenbacher, del L. Re, H. Kokal, M. Schmidt, M. Paulweber // Proceedings of the 17th World Congress The International Federation of Automatic Control. - Barselona, 2008. - P. 9479-9484.

6. Inverse Torque Control of Hydrodynamic Dynamometers for Combustion Engine Test Benches / T.E. Passenbrunner, M. Sassano, H. Trogmann, del L. Re, M. Paulweber, M. Schmidt, H. Kokal // Proceedings of the American Control Conference. - USA, August 2011. - P. 4598-4603.

7. Van den Braembussche R.A. Dynamic Stability of a water brake dynamometer / Van den R.A. Braembussche, H. Malys // Journal of Engineering for Gas Turbines and Power. - 1998. - № 120. - P. 89-96.

8. Экспериментальное исследование колебательных процессов при испытаниях турбовинтового двигателя на гидротормозной установке / А.Г. Гимадиев, В.А. Букин, П.И. Грещняков, А.В. Уткин // Материалы международной научнотехнической конференции. - Самара, 22-24 июня 2016 г. - С. 20-21.

9. Torabnia S. Development of a water brake dynamometer with regard to the modular product design methodology [Електронний ресурс] / S. Torabnia, A. Banazadeh // 12th Biennial Conference on Engineering Systems Design and Analysis, 25-27 July 2014. - Copenhagen, Denmark. - Режим доступу: https://asmedigitalcollection.asme.org/ESDA/proceedingsabstract/ESDA2014/45837/V001T05A005/232146.

10. Головащенко А. Осьминог или о роли тормоза в прогрессе турбостроения / А. Головащенко // Двигатель. 2004. - № 4. - C. 16-54.

11. Иноземцев А.А. Автоматика и регулирование авиационных двигателей и энергетических установок / А.А. Иноземцев, М.А. Нихамкин и др. - М.: Машиностроение, 2008. - 200 с.

\section{References}

1. Popov, G., Novikova, Yu., Goryachkin, E. (2016), "Ispolzovanie kompressora nizkogo davleniya dlya sozdaniya gidrotormoznoy sistemyi ispyitatelnogo stenda gazoturbinnyih dvigateley" [Using a low-pressure compressor to create a hydraulic brake system for a test bench for gas turbine engines], Materials of The International Scientific and Technical Conference. Samara, SNIU, pp. 132-133.

2. Hait, L. Husainov, R., Soldatov, V. and Golovin, M. (2018), "Sistema avtomatizatsii seriynyih stendovyih ispyitaniy aviatsionnyih dvigateley" [Automation system for serial bench tests of aircraft engines], Modern Automation Technologies, No. 4, pp. 76-81.

3. Sedristyiy, V., Loznya, S., Pustovoy, S. and Stepanenko, I. (2009), "Opyit razrabotki i primeneniya intellektualnyih ispyitatelnyih stendov aviatsi-onnyih gazoturbinnyih dvigateley pri dovodke tsifrovyih SAU" [Experience in the development and application of intelligent test benches of aircraft gas turbine engines in the development of digital SAC], Bulletin of the Academy of Engineering of Ukraine, No. 1, pp. 158-164.

4. Sykes, C.L., Sagehorn, K.H. Systems and Methods for Controlling the Stability of a Water Brake Dyna-mometer. United States Patent US7.942.249 B2.

5. Gruenbacher, E., del Re, L., Kokal, H., Schmidt, M., Paulweber, M. (2008), Adaptive control of engine torque with input delays, Proceedings of the 17th World Congress The International Federation of Automatic Control, Barselona, pp. 9479 9484.

6. Passenbrunner, T.E., Sassano, M., Trogmann, H., del Re, L., Paulweber, M., Schmidt, M. and Kokal, H. (2011), Inverse Torque Control of Hydrodynamic Dynamometers for Combustion Engine Test Benches, Proceedings of the American Control Conference, August, USA, pp. 4598-4603.

7. Van den Braembussche, R.A. and Malys, H. (1998), Dynamic Stability of a water brake dynamometer, Journal of Engineering for Gas Turbines and Power, No. 120, pp. 89-96.

8. Gimadiev, A., Bukin, V., Greshchnyakov, P. and Utkin, A. (2016), "Ehksperimentalnoe issledovanie kolebatelnykh protsessov pri ispytaniyakh turbo-vintovogo dvigatelya na gidrotormoznoi ustanovke" [An experimental study of oscillatory processes during testing of a turboprop engine in a hydraulic brake installation], Materials of the International Scientific and Technical Conference, 22-24 June, Samara, pp. 20-21. 
9. Torabnia, S. and Banazadeh, A. (2014), Development of a water brake dynamometer with regard to the modular product design methodology, Proceedings of the ASME 2014, 12th Biennial Conference on Engineering Systems Design and Analysis, 25-27 July, Copenhagen, Denmark, available at: https://asmedigitalcollection.asme.org/ESDA/proceedingsabstract/ESDA2014/45837/V001T05A005/232146.

10. Golovashenko, A. (2004), "Osminog ili o roli tormoza v progresse turbostroeniya" [Octopus or the role of the brake in turbine progress], Engine, No. 4, pp. 16-54.

11. Inozemtsev, A.A. and Nikhamkin, M.A. (2008), "Avtomatika $i$ regulirovanie aviatsionnykh dvigatelei $i$ ehnergeticheskikh ustanovok" [Automation and regulation of aircraft engines and power plants], Mashinostroenie, Moscow, $200 \mathrm{p}$.

Надійшла до редколегії 04.02.2020

Схвалена до друку 10.03.2020

\section{Відомості про авторів:}

\section{Литвяк Олександр Миколайович}

кандидат технічних наук доцент доцент кафедри Національного університету цивільного захисту України,

Харків, Україна

http://orcid.org/0000-0002-0242-1859

Комар Сергій Володимирович кандидат технічних наук доцент старший викладач кафедри

Харківського національного університету

Повітряних Сил ім. І. Кожедуба,

Харків, Україна

https://orcid.org/0000-0002-8961-2614

\section{Information about the authors:}

\section{Oleksandr Litviak}

Candidate of Technical Sciences Associate Professor

Senior Lecturer of National University

of Civil Protection of Ukraine,

Kharkiv, Ukraine

http://orcid.org/0000-0002-0242-1859

\section{Sergii Komar}

Candidate of Technical Sciences Associate Professor

Senior Instructor

of Ivan Kozhedub Kharkiv National

Air Force University,

Kharkiv, Ukraine

https://orcid.org/0000-0002-8961-2614

\title{
ОБОСНОВАНИЕ ЗАКОНОВ РЕГУЛИРОВАНИЯ ГИДРОТОРМОЗНОЙ УСТАНОВКИ ДЛЯ НАЗЕМНЫХ ИСПЫТАНИЙ ТУРБОВАЛЬНЫХ ГТД
}

\author{
А.Н. Литвяк, С.В. Комар
}

В статье рассматриваются проблемы, возникающие при наземных испытаниях авиационных турбовальных газотурбинных двигателей на гидротормозных установках. Представлены экспериментальные загрузочные характеристики гидротормоза и несущего винта вертолета. Показано, что несоответствие загрузочных характеристики гидротормоза соответствуюшим характеристикам несущего винта может привести к неудовлетворительной работе регулятора частоть вращения ротора свободной турбинь двигателя. Дано обоснование закона регулирования загрузкой гидротормоза, обеспечивающего загрузочные характеристики близкие к загрузочным характеристикам несущего винта вертолета. Показано, что гидротормозная установка с системой автоматического управления загрузкой позволяет приблизить динамические характеристики гидротормоза к динамическим характеристикам несущего винта вертолета и обеспечить корректные наземные испытания турбовальных ГТД.

Ключевые слова: Наземные испытания турбовальных ГТД, гидротормоз, загрузочная характеристика, динамические параметры, закон регулирования, переходные характеристики, регулятор частоты вращения свободной турби$\mathrm{Hbl}$.

\section{SUBSTANTIATION OF LAWS OF REGULATION OF A HYDRAULIC BRAKE FOR GROUND TESTS OF TURBOSHAFT GAS TURBINE ENGINES}

\author{
O. Litviak, S. Komar
}

In ground tests of turboshaft gas turbine engines, an unsatisfactory operation of the system for automatically controlling the speed of a free turbine, which manifests itself as steady-state fluctuations in engine parameters, is often noted. To absorb the power generated by a free turbine, hydraulic brake systems of various designs are used in ground tests of aircraft turboshaft gas turbine engines. Ground tests of aircraft turboshaft gas turbine engines with the use of such hydraulic brakes can result in emergency modes of automated engine control in the area of operation of a free turbine speed regulator. Mismatch between the hydraulic brake loading characteristics and the loading characteristics of the rotor driven by a free turbine of the engine is the main cause of emergency operation of automated control systems. Changing the design of the hydraulic brake in order to change its characteristics is a very laborious and expensive task. Therefore, the paper considers the possibility of providing the specified characteristics of the hydraulic brake with simple automation. The presented experimental loading characteristics of the hydraulic brake and the helicopter rotor show their significant difference in terms of gain. To eliminate this difference, a possibility of modeling dynamic parameters of rotors by simple automation means was considered. To solve this problem, a linear dynamic model and a block diagram of an automated hydraulic brake control system for ground testing of turboshaft gas turbine engines were elaborated. The law of regulation of the hydraulic brake loading was substantiated. A structurally dynamic diagram of the developed automated control system was presented and calculation formulas for determining the regulator parameters were given. Transient characteristics of the hydraulic brake unit without automation means and with the use of an automated loading control system were calculated. The presented calculation results have shown that the use of automation make it possible to fully emulate characteristics of the helicopter rotors.

Keywords: ground tests of turboshaft gas turbine engines, hydraulic brake loading characteristic, dynamic parameters, regulation law, transient characteristics, speed controller of a free turbine. 